DOI 10.36074/05.06.2020.v4.21

\title{
REVIEW OF LEGISLATIVE INITIATIVES IN THE FIELD OF PRIVATE DETECTIVE (SEARCH) ACTIVITIES
}

\author{
Kateryna Chyshko \\ Candidate of Juridical Sciences, \\ Senior Lecturer of the Department of Police Activity and Public Administration \\ Kharkiv National University of Internal Affairs
}

UKRAINE

A systematic study of the provisions of the draft law On private detective (search) activity dated September 2, 2019 № 1228 [1] made it possible to identify a number of inaccuracies.

In Part 1 of Article 3 of the draft law establishes the principle of interaction with law enforcement agencies, state authorities and local governments, enterprises, institutions, organizations and citizens. At the same time, the current legislation, like the theory of law, defines the list of law enforcement agencies in different ways. Given that the clarity of the meaning of the principle directly affects the quality of its implementation, it is necessary to specifically determine the list of law enforcement agencies, in addition, there are no judicial authorities in this edition, which are often not referred to law enforcement bodies in the legislative and scientific fields. Moreover, law enforcement agencies are public authorities in court. Considering the above, it is recommended to lay out Part 1 Article 3 of the draft law as follows:

«Private detective (detective) activity is based on the principles of the rule of law, legality, dispositiveness, objectivity and impartiality, respect for the rights, freedoms and legitimate interests of individuals and legal entities, respect for human dignity, honesty, independence of subjects of private detective (search) activity, confidentiality and preservation of professional secrets, interaction with state authorities and local authorities, enterprises, institutions, organizations and citizens.».

In Part 3 Article 4 of the draft law On private detective (search) activity indicates that the subjects of private detective (search) activity are not subject to the laws governing the legal status of law enforcement officials. This norm cannot be considered correct, because in addition to specialized laws, these entities are also subject to the norms of the Ukrainian Code of Labor Laws, which private detectives will use in their work in the future. It is recommended that the indicated norm be deleted.

The content of Part 5 Article 4 of the draft law On private detective (search) activity designates such activity as exclusive for subjects of private detective (search) activity. In this context, it remains unclear what an exceptional type of activity is, because if it is carried out by business entities, and private detectives just have such an organizational and legal form, then this is an economic activity that can be profitable or unprofitable, etc., and here about exclusive types of activity in the current legislation does not contain any provisions. Moreover, it is not clear why private detective (search) activity is exclusive to private detectives. It is also recommended that the indicated norm be deleted.

Summing up, it should be noted that the main draft normative legal act, which in the future may become the basis for the formation of the institution of private detectives, requires further improvement, in particular, taking into account existing and promising doctrinal developments. 